\title{
ЦИВІЛЬНО-ПРАВОВА ВІДПОВІДАЛЬНІСТЬ МЕДИЧНИХ ПРАЦІВНИКІВ В УКРАЇНІ
}

\author{
КНЯЗЬКА Лілія Антонівна - кандидат юридичних наук, доцент кафедри \\ цивільного права та процесу, Університет фіскальної служби України \\ DOI 10.32782/NP.2021.3.23
}

\begin{abstract}
У статті досліджуються питання цчивільно-правової відповідальності медичних працівників в Украӥні. Акцентується увага, щ⿻ розвиток ицвільних правовідносин у галузі охорони здоров'я призводить до появи в изій галузі суспільної діяльності питомої ваги приватноправових, переважно договірних методів регулювання медичноїдіяльності, що надає пацієнтам можливість використовувати механізми, засоби иивільно-правової відповідальності для захисту свойх прав. На съогоднішній день високий ступінь відповідальності, що покладається на медичного прачівника, в основному, пов'язаний з думкою про те, що він як би отримуе у свої руки найбільш значиму суспільну цзінність життя $і$ здоров'я людини, причому у більшості випадків людини хворої, тобто такої, що вже знаходиться у небезпеці.
\end{abstract}

Аргументується, що иивільно-правова відповідальність в медичній галузі - $\epsilon$ одним $i_{3}$ видів професійної відповідальності, настає у випадках порушення або невиконання медичною установою, медичними працівниками свойх професійних обов'язків, що призводить до появи певних негативних наслідків у вигляді завдання шкоди життю, здоров'ю паиієнта або інших осіб. Зважаючи на те, що Украӥна та увесь світ потерпає від коронавірусної інфекцій, питання цивільно-правової відповідальності медичних працівників набуває особливої актуальності.

Робляться висновки, що иивільно-правова відповідальності медичних працівників виступає реалізацією санкиіі правової норми, шо є за своїм характером засобом примусу, супроводжутться осудом з боку держави $i$ потерпілого, $і$ виражається в покладанні на винного у порушенні суб’єкта невигідних для нъого наслідків порушення нематеріального чи матеріального характеру. При иъому ключовими ознаками можна назвати: вона являе собою реалізацію санкиій иивільно-правової норми; за своїм характером є засобом державного примусу або засобом приватного впливу, що забезпечений можливістю державного примусу; є наслідком протиправноӥ поведінки суб'єкта права; може виникати із пасивної поведінки суб'єкта; супроводжується вираженим або таким, шьо мається на увазі, осудом винної особи (медичних працівників) з боку пацієнта (родичів) та держави; виражається у покладенні на винного у вчиненні правопорушення суб'єкта додаткових обтяжень матеріального або особистого характеру тощо.

Ключові слова: медицина, чивільноправова відповідальність, право на охорону здоров'я, лікар, пацієнт.

\section{Актуальність}

Право людини на охорону здоров'я 6 одним із визначальних серед природних, невід'ємних, невідчужуваних і непорушних прав людини. Воно гарантує кожній людині як члену громадянського суспільства невтручання держави у сферу ії особистого і сімейного життя, захист іï життя і здоров'я, особисту недоторканність й безпеку тощо. Таке конституційне право забезпечує особисту свободу, незалежність і самостійність особи, гарантує життя і захист від будь-яких форм насильства, жорстокого й такого, що прини- 
жує людську гідність, ставлення. Це право індивідуалізує людину та сприяе особистій свободі, тобто можливості безперешкодного вибору різних варіантів поведінки у межах соціальних відносин, що є однією з умов активної життедіяльності.

Розвиток цивільних правовідносин у галузі охорони здоров'я призводить до появи в цій галузі суспільної діяльності питомої ваги приватноправових, переважно договірних методів регулювання медичної діяльності, що надає пацієнтам можливість використовувати механізми, засоби цивільно-правової відповідальності для захисту своїх прав.

На сьогоднішній день високий ступінь відповідальності, що покладається на медичного працівника, в основному пов'язаний 3 думкою про те, що він як би отримує у свої руки найбільш значиму суспільну цінність життя і здоров'я людини, причому у більшості випадків людини хворої, тобто такої, що вже знаходиться у небезпеці. Останнє часто пов'язано 3 недотриманням індивідуумом здорового способу життя і безвідповідальною поведінкою у відношенні до свого здоров'я. У той же час, сповідуючи довіру до медичних працівників, суспільство намагається встановити жорсткий контроль за їх діяльністю, у тому числі шляхом використання механізмів юридичної відповідальності.

Цивільно-правова відповідальність в медичній галузі - є одним із видів професійної відповідальності, настає у випадках порушення або невиконання медичною установою, медичними працівниками своїх професійних обов'язків, що призводить до появи певних негативних наслідків у вигляді завдання шкоди життю, здоров'ю пацієнта або інших осіб. Зважаючи на те, що Україна та увесь світ потерпає від коронавірусної інфекції, питання цивільно-правової відповідальності медичних працівників набуває особливої актуальності.

\section{Аналіз останніх досліджень та публікацій}

Питання цивільно-правової відповідальності медичних працівників вже протягом довгого часу залишаються одними із найбільш обговорюваних у наукових колах. Так, серед науковців-правників із означеної тема- тика варто згадати про публікації та дослідження: Р.Ю. Гревцової, П.Й. Кузьмінського, Т.Й. Білоус, Т.В. Заварза, С.А. Загороднього, P.А. Майданик, О.В. Артеменко, I.B. Горіславської, В.П. Паліюк, І.Я. Сенюти, С.Г. Стеценко, В.Ю. Стеценко, Р.О. Стефанчука та інших.

Метою даного дослідження виступає комплексний аналіз цивільно-правової відповідальності медичних працівників в Україні.

\section{Результати}

Відповідальність медичних працівників, лікувально-профілактичних закладів та інших установ системи охорони здоров'я $\epsilon$ досить гострою медико-юридичною проблемою, для вирішення якої необхідно не тільки проводити наукові дослідження, але й прикладати певні зусилля з впровадження їх результатів у практичну площину.

I.B. Горіславська зазначає, що безпека пацієнтів є глобальною проблемою, котра зачіпає країну на всіх етапах іiї розвитку. I така безпека, на ії глибоке переконання, буде виражатися насамперед в існуванні ефективних договорів 3 надання медичних послуг (Горіславська I.В. «До питання...», 2019: 110).

Артеменко О.В. справедливо зауважує, що держава зобов'язана створювати умови для доступного та ефективного для усіх громадян медичного обслуговування. Адже, не можливо уявити процвітаючу та економічно стабільну державу із хворою нацією, що і стає обов'язком держави по створенню умов для захисту населення, а також надання належного медичного обслуговування (Артеменко О. В., Князька А.А. «Особливості правової...», 2020: 77).

Зарубіжні науковці одностайні в тому питанні, що відносини між лікарем і пацієнтом базуються на засадах юридичної рівності та вільного волевиявлення, регулюються приватним правом, і вони є цивільно-правовими відносинами (G. Jobbágyi. «Az orvos-beteg...» 2005:16)

Проте, на думку К.Б. Ярошенко, відносини між лікувальним закладом та пацієнтом самі по собі цивільним правом не регулюються, а потрапляють у сферу регулювання 
цивільного права, коли лікувальний заклад не виконує або неналежним чином виконує свої публічні обов'язки і цим заподіює шкоду потерпілому і має обов'язок їі відшкодувати. Такими відносинами він вважає деліктні зобов'язання (Ярошенко К.Б. «Життя та здоров’я..» 1990:27).

За загальним правилом, мірою відповідальності служить не ступінь провини, а величина заподіяної шкоди, залежно від якої і дається правова оцінка поведінки медперсоналу і наступає відповідна їй юридична відповідальність (Антонов С.В. «Особливості відшкодування..» 2007: 99). У разі медичної відповідальності за проступки лікаря, позадоговірні збитки відшкодовуються лікарем або закладом охорони здоров'я. Якщо відносини лікаря та пацієнта є цивільно-правовими відносинами, то у разі виникнення відповідальності має важливе значення, що є підставою виникнення, зміни та припинення цих правовідносин, тобто юридичним фактом. Відповідь на це питання залежить від того, це договірні чи позадоговірні зобов'язання (Булеца С.Б. Цивільно-правова..» 2014: 24).

Особливостями цивільно-правової відповідальності медичних працівників Коробцова Н. В. називає:

- заходи такої відповідальності застосовуються лише при порушенні конкретних прав пацієнта та наявності відповідної шкоди в особистій або майновій сфері особи. Наявність шкоди є обов'язковою умовою настання цивільно-правової відповідальності в медичних правовідносинах. Шкода може мати вираз у матеріальних збитках (витратах на лікування, купівлі ліків) і нематеріальній (моральній) формі;

- відповідальність за правопорушення в медичній сфері часто має двосторонній взаємний характер. Пацієнт може висунути виконавцю вимоги про отримання послуги неналежної якості або не в повному обсязі, а виконавець - заявити про порушення договору з боку пацієнта (несвоєчасна оплата послуг, порушення пацієнтом рекомендацій лікаря, плану лікування тощо);

- в зобов'язальних правовідносинах діє принцип презумпції вини, тобто особа $є$ невинуватою, якщо вона доведе, що вжила всіх залежних від неї заходів щодо належного ви- конання зобов’язання (ч. 1 ст. 614 ЦК України). Відсутність своєї вини доводить особа, яка порушила зобов'язання (ч. 2 ст. 614 ЦК України);

- встановлений обов’язок потерпілої сторони (пацієнта) доводити факт правопорушення, наявність заподіяної йому шкоди та причинний зв’язок між діями виконавця послуги та негативними наслідками. Причинний зв'язок повинен існувати об'єктивно і бути тією причиною, яка зумовила виникнення шкоди. Медичні працівники при виконанні своїх професійних обов'язків повинні дотримуватися не лише приписів законів, спеціальних нормативних актів, але й звичаїв, певних правил, які склалися в медичній практиці, недотримання або порушення яких буде вважатися протиправною поведінкою. Протиправна поведінка може мати вияв як у формі активних дій, так і бездіяльності (Коробцова, Д. В. «Актуальні питання..» 2020:40).

Важливе значення при дослідженні цивільно-правової відповідальності мають суб'єкти, що можуть зазнавати заходів цивільно-правової відповідальності. Так, відповідно до ч. 1 ст. 1172 ЦК України такими суб'єктами можуть бути медичні установи, які відповідають за шкоду, завдану їхніми працівниками під час виконання своїх трудових обов'язків (ЦК України). У тому разі, якщо шкода була завдана лікарем, який зареєстрований як суб'єкт підприємницької діяльності i, маючи ліцензію на медичну практику, надає медичні послуги такої якості, відповідає за завдану пацієнту шкоду особисто.

Проаналізувавши судову практику, Білоус Т.Й. зазначає, що останнім часом збільшилась кількість позовів пацієнтів про притягнення до відповідальності медичних закладів та медичних працівників загалом. До них належать справи про відшкодування майнової та/або моральної шкоди, завданої ушкодженням здоров'я, спричиненого неналежним лікуванням. Медичних працівників дедалі частіше звинувачують у неправильно поставленому діагнозі, а також невірно підібраному курсі лікування, призначенні неповного лікування відповідно до діагнозу, неналежному наданні медичної допомоги, що стало причиною інвалідності чи смерті пацієнта тощо. 


\section{Цивільне, підприсмницьке, господарське та трудове право}

При цьому, як випливає 3 аналізу норм Цивільного кодексу України, шкода, завдана пацієнту при наданні медичних послуг, підлягає відшкодуванню в повному обсязі. Aле при застосуванні заходів договірної відповідальності цілком виправданим буде закріплення в договорі додаткових заходів цивільно-правової відповідальності виконавця. Тобто встановлення обов'язку виконавця послуг здійснити виплати пацієнту в більшому розмірі, ніж це передбачено законом, іншими словами, встановити підвищену відповідальність виконавця послуг (придбання путівок до санаторію, додаткові реабілітаційні заходи, придбання ліків за рахунок виконавця).

Якщо в договорі розмір компенсації матеріальних збитків все ж можливо розрахувати, визначити, то розмір моральної шкоди та в чому вона безпосередньо буде мати вияв, передбачити не можливо. За наявності грубої необережності, вини потерпілої особи та інших обставин розмір компенсації збитків може зменшуватися. При цьому умовами договору не може передбачатися стягнення збитків у меншому розмірі, ніж це передбачено в законі, однак, якщо така ситуація виникне, пацієнт завжди зможе стягнути «не охоплені» договором збитки за правилами недоговірної відповідальності (Коробцова Д. В. «Актуальні питання..» 2020: 42).

\section{Висновки і перспективи}

Здійснивши комплексний аналіз цивільно-правової відповідальності медичних працівників, можна дійти до висновків, що такою відповідальністю є реалізація санкції правової норми, що за своїм характером є засобом примусу, супроводжується осудом з боку держави і потерпілого, і виражається в покладанні на винного у порушенні суб'єкта невигідних для нього наслідків порушення нематеріального чи матеріального характеру. При цьому ключовими ознаками можна назвати: вона являє собою реалізацію санкції цивільно-правової норми; за своїм характером є засобом державного примусу або засобом приватного впливу, що забезпечений можливістю державного примусу; є наслідком протиправної поведінки суб'єкта права; може виникати із пасивної поведінки суб'єкта; супроводжується вираже- ним або таким, що мається на увазі, осудом винної особи (медичних працівників) з боку пацієнта (родичів) та держави; виражається у покладенні на винного у вчиненні правопорушення суб'єкта додаткових обтяжень матеріального або особистого характеру; є для порушника додатковим обов'язком до таких обов'язків, що вже існували раніше внаслідок припису норми акта законодавства, договору і не були виконані порушником; реалізується у відповідних процесуальних формах (у приватних відносинах може бути реалізована добровільно, але у випадку ухилення порушника від виконання покладеного на нього додаткового обов'язку, знову-таки реалізується за допомогою державного примусу, що здійснюється у відповідних процесуальних формax).

\section{入ітература}

1. Горіславська I.В. До питання деліктної відповідальності медичних працівників у системі безпеки пацієнтів в Україні та світі. Право. Аюдина. Довкілля: науково-практичний журнал. 2019. Том 10. № 4. С. 106-114.

2. Artemenko, Olena; kniazka, Liliia. Ocoбливості правової природи договорів про надання медичних послуг (медичного обслуговування) в Україні. Науково-практичний журнал «Право. Аюдина. Довкілля», [S.1.], v. 11, n. 1, р. 76-84, кві. 2020. ISSN 2663-1369. URL: http://journals.nubip.edu.ua/index.php/ Pravo/article/view/13835/1216

3. Jobbágyi Gábor. Az orvos-beteg jogviszony az új Ptk.-ban. PJK.- 2005.-1.- 15-20. o./ URL: http:/ptk2013.hu/polgari-jogi-kodifikacio/jobbagyi-gabor-az-orvos-beteg-jogviszony-az-uj-ptkban-pjk-20051-15-20-o/330

4. Ярошенко К.Б. Жизнь и здоровье под охраной закона. Юрид. лит-ра, 1990.-174 с.

5. Антонов С.В. Особливості відшкодування шкоди заподіяної пацієнтові невдалим медичним втручанням. Управління закладом охорони здоров’я. 2007. № 7. С. 22-26.

6. Булеца С.Б. Цивільно-правова відповідальність в сфері здійснення медичної діяльності. Право і громадянське суспільство. 2014. № 1. С. 204.

7. Коробцова Д. В. Актуальні питання цивільно-правової відповідальності за правопорушення в медицині. Актуальні проблеми 
вітчизняної юриспруденції. 2020. № 2. С. 39-

42. URL: https://doi.org/10.15421/392039

8. Цивільний кодекс України від 16.01.2003 р. № 435-IV. Відомості Верховної Ради України (ВВР). 2003. № 40-44. Ст. 356 (з останніми змінами).

9. Білоус Т.Й. Цивільно-правова відповідальність медичних працівників. Юридичний науковий електронний журнал № 4/2019 URL: https://doi.org/10.32782/2524-0374/2019-4/9

\section{References}

1. Gorislavska I.V. On the issue of tortious liability of medical workers in the patient safety system in Ukraine and the world. Right. Man. Environment: scientific and practical journal. 2019. Volume 10. № 4. pp. 106-114.

2. ARTEMENKO, Olena; KNIAZKA, Liliia. Features of the legal nature of contracts for the provision of medical services (medical care) in Ukraine. Scientific and practical journal «Law. Man. Environment ", [S.1.], v. 11, n. 1, p. 7684, April. 2020. ISSN 2663-1369. URL: http:// journals.nubip.edu.ua/index.php/Pravo/article/ view/13835/1216

3. Jobbágyi Gábor. Orvos-beteg jogviszony az új Ptk.-ban. PJK.- 2005.-1.- 15-20. o./ URL: http://ptk2013.hu/polgari-jogi-kodifikacio/ jobbagyi-gabor-az-orvos-beteg-jogviszony-az-ujptk-ban-pjk-20051-15-20-o/330

4. Yaroshenko K.B. Life and health under the protection of the law. Jurid. lit-ra, 1990.-174 p.

5. Antonov S.V. Features of compensation for damage caused to the patient by a failed medical intervention. Health facility management. 2007. № 7. S. 22-26.

6. Buletsa S.B. Civil liability in the field of medical activities. Law and civil society. 2014. № 1. S. 204.

7. Korobtsova D.V. Current issues of civil liability for offenses in medicine. Actual problems of domestic jurisprudence. 2020. № 2. pp. 3942. URL: https://doi.org/10.15421/392039

8. Civil Code of Ukraine of January 16, 2003 № 435-IV. Information of the Verkhovna Rada of Ukraine (VVR). 2003. № 40-44. St. 356 (as last updated).

9. Belous T.Y. Civil liability of medical workers. Legal scientific electronic journal № 4/2019 URL: https://doi.org/10.32782/25240374/2019-4/9

\section{GIVIL LEGAL LIABILITY OF MEDICAL WORKERS IN UKRAINE}

The article examines the issues of civil liability of medical workers in Ukraine. It is emphasized that the development of civil legal relations in the field of health care leads to the emergence in this area of public activity of the share of private, mostly contractual methods of regulating medical activities, which allows patients to use mechanisms, means of civil liability to protect their rights. To date, the high degree of responsibility imposed on the health worker is mainly due to the idea that he seems to receive in his hands the most important social value - human life and health, and the person in most cases a sick person. , ie one that is already in danger.

It is argued that civil liability in the medical field - is a type of professional liability, occurs in cases of violation or non-performance by a medical institution, medical workers of their professional duties, which leads to certain negative consequences in the form of harm to life, health. patient or others. Given that Ukraine and the whole world suffers from coronavirus infection, the issue of civil liability of health care workers becomes especially relevant.

It is concluded that the civil liability of medical workers is the implementation of the sanction of the rule of law, which is by nature a means of coercion, accompanied by condemnation by the state and the victim, and is expressed in the imposition on the guilty of violating of a material nature. The key features are: it is the implementation of the sanction of civil law; by its nature is a means of state coercion or a means of private influence, provided with the possibility of state coercion; is a consequence of illegal behavior of the subject of law; may arise from the passive behavior of the subject; accompanied by a pronounced or implied condemnation of the guilty person (medical staff) by the patient (relatives) and the state; is expressed in the imposition on the perpetrator of the offense of the subject of additional burdens of material or personal nature, etc.

Key words: medicine, civil liability, right to health care, doctor, patient. 